\title{
Environmental Sanitation and Peri-Domiciliar Organisation as Auxiliary Practices for the Control of Phlebotomines in Paraná State, Southern Brazil
}

\author{
Ueslei Teodoro ${ }^{1}$, João Balduíno ${ }^{1}$, Vanete Thomaz-Soccol ${ }^{2 *}$, Orlando C. Barbosa ${ }^{3}$, Maria E. \\ M. C. Ferreira ${ }^{4}$, Ana Leuch Lozovei ${ }^{2}$, Thaís G. Verzignassi, Andrea C. B. Silva Roberto ${ }^{1}$ \\ ${ }^{I}$ Departamento de Análises Clínicas, Universidade Estadual de Maringá, Av. Colombo, 5.790, Maringá, PR, Brasil, \\ 87020-900, ${ }^{2}$ Departamento de Patologia Básica, Universidade Federal do Paraná-Centro Politécnico, Curitiba, \\ Paraná, ${ }^{3}$ Fundação Nacional de Saúde, Distrito de Londrina, PR, ${ }^{4}$ Departamento de Geografia, Universidade \\ Estadual de Maringá.
}

\begin{abstract}
Studies were conducted to compare the results of the collections of phlebotomines, in two distinct periods, i.e. before and after changed environmental conditions in Jussara county, Paraná State, Brazil. Collections were made near to a forest in Jussara farm, between February and April 1992. Six Falcão light traps were installed in houses and animals' shelters. Catches were made once a month and 35,783 phlebotomines were captured. Based on these data, sanitation was done in peridomiciliary area and domestic animals shelters were separated from domiciles in January 1994. Then during February to April 1994 using the same methodology new phlebotomines catches were made. The results showed that an average of just 150 (6,311/42) phlebotomines per hour were collected at this time in contrast with an average of 3,976 (35,783/9) in 1992. The separation of domestic animals shelters from human dwelling may contribute to diminish the phlebotomine population and attenuate the risk of Leishmania_transmission in endemic areas of cutaneous leishmaniasis.
\end{abstract}

Key words: Leishmaniasis - Psychodidae - Phlebotomine - Sandflies - Ecology - Lutzomyia.

\section{INTRODUCTION}

The growing number of cutaneous leishmaniasis cases in Brazil requires an urgent need to give priority to the technical education of professionals involved in the health care, and the supply of laboratory resources and drugs. Lack of these resources is a hindrance in diagnosis and disease treatment (Lainson 1985, Marsden 1985, 1986, Ward 1977). In Paraná State the situation is no different from the rest of Brazil (Teodoro et al. 1991).

There are some reports describing leishmaniasis prophylactics in Brazil which are mainly based on the use of synthetic insecticide (Alencar 1961, Brazil et al., 1992, Deane et al. 1955, Magalhães et al., 1980, Nery-Guimarães \&
Bustamante 1954), envisaging their periodic and constant use. However, due to lack of specific programmes, implementation of a chemical control has not been effective and there is a need for alternatives methods, involving the community itself and not only Governmental bodies. Several authors have drawn attention towards the poor hygiene conditions and disorganised domicile and peri-domicile environments, in both the rural as well urban areas, where phlebotomines have been abundantly trapped (Lima et al. 1981,1988; Mattos 1981; Souza et al.; 1981 Gomes et al. 1986; Teodoro 1995).

Collections of phlebotomines in forest and extraforest environments clearly showed that the number of insects in the latter was considerably

\footnotetext{
* Author for correspondence
} 
higher than in the former, mainly, in domestic animals huts, such as pigs, hens donkeys, dogs etc. (Gomes et al. 1980; Mattos 1981; Teodoro et al. 1993; Teodoro 1995).

The aim of this work was to compare phlebotomines frequencies in the house and peridomestic area within a rural region with scattered houses, during two collecting phases, which were related to changes in the sanitary and environmental conditions.

\section{MATERIALS AND METHODS}

\section{Research area description:}

Jussara Farm, located in the municipality of Jussara, the northwestern region of the Paraná State, was chosen as the area of work (cf. Teodoro, 1995).

The sites where phlebotomines collections have been made shows the following characteristics:

Houses that were aligned on the lower part of a slope segment in SSW direction, 80-100 m away from the Água do Encontro creek;

Houses front facing towards (NNE), higher than and $40 \mathrm{~m}$ away from a secondary woody area (predominantly "pau-jacaré");

House fronts facing brightest lit quadrant (NNE) and a number of palm-trees, tuya's and "spring" have been planted;

On the NNW side there is a very old and large Pinus reforestation area (settled around 1956), with several trees reaching 30-35 m high;

To the East there is a small wood strip, continuing as bordering forest along the Água do Encontro creek: it consists of partially destroyed woody native flora, with partial elimination of the shrubby and crawling extract and planting of palm-trees;

House backs, facing the Água do Encontro creek valley, towards the final segment of the small slope, with a relatively steeper slope starting from the slope break, beginning just a few metres away from the buildings;

The place was occupied by pigs, hens, cowsheds, water tanks amid orange-, tangerine-, guava- and banana-trees;

Shadowing was evident, particularly as the slope was locally facing SSW, the most shaded and coldest quadrant;

Soil was relatively humid even at 5-10\% steep;

20-30 m away from the houses backs, lies a grazing strip, with a variable width $(20-50 \mathrm{~m})$, until the limit of the low-density bordering forest along the Água do Encontro creek (Figure 1 and 2).

\section{Phlebotomines capture method:}

The phlebotomine collections were made during two phases, at the same place, though in different environmental conditions. In the first phase, the phlebotomine capture was made with Falcão (1981) light-traps, during February, March and April 1992, once a month, in the second half of the month, from 9:00 to 12:00 p.m. for a total of $9 \mathrm{~h}$. Six traps were installed within the domicile and the peri-domicile area of a group of houses, beside the forest of Jussara farm (Figure 1) as described below:

a) in a pigsty $(\mathrm{P})$, in the back of house 1;

b) within house $1(\mathrm{R})$;

c) in a shed (E), with a horse serving as a bait;

d) in the varanda of house $3(\mathrm{~T})$, uninhabited during that period;

e) in a dog hut (C);

f) in the internal part of a hens' shed

g) in the back of house 4 .

During the first collection period, no environmental modifications were made. Soil humidity was high, because of the wet surface of the house (sewage water) and the shade originated by the ornamental and fruit-trees. There was accumulation organic matter in the environment due to animal faeces, leftover from food offered to the animals, decomposing fruits and leaves. 


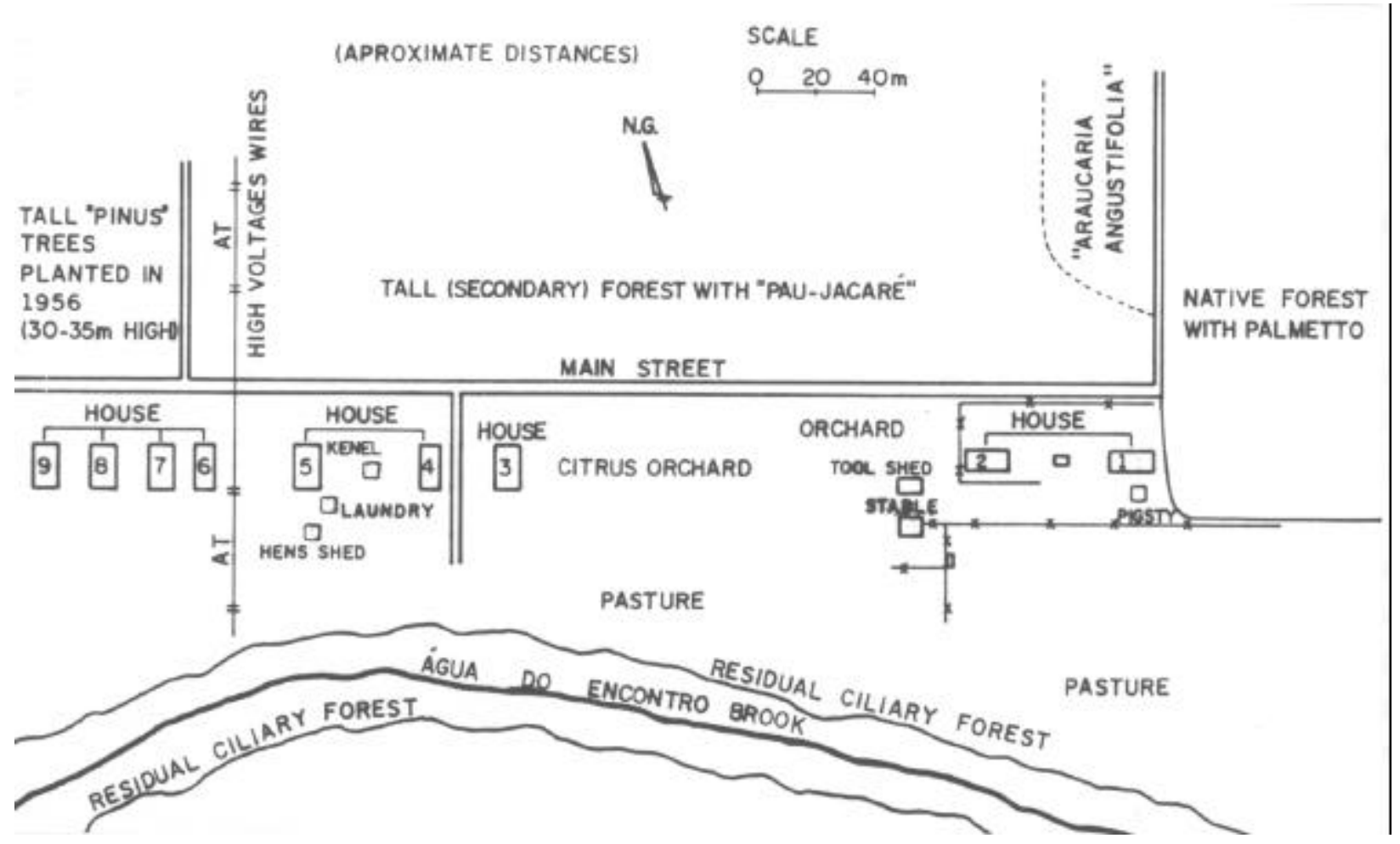

Figure 1: Falcão traps installed inside hens shed, kennel, house 4, stable, house 1 and pigsty before prophylactic measures in February, March and April 1992, in Jussara Farm, Parana State, Brazil.

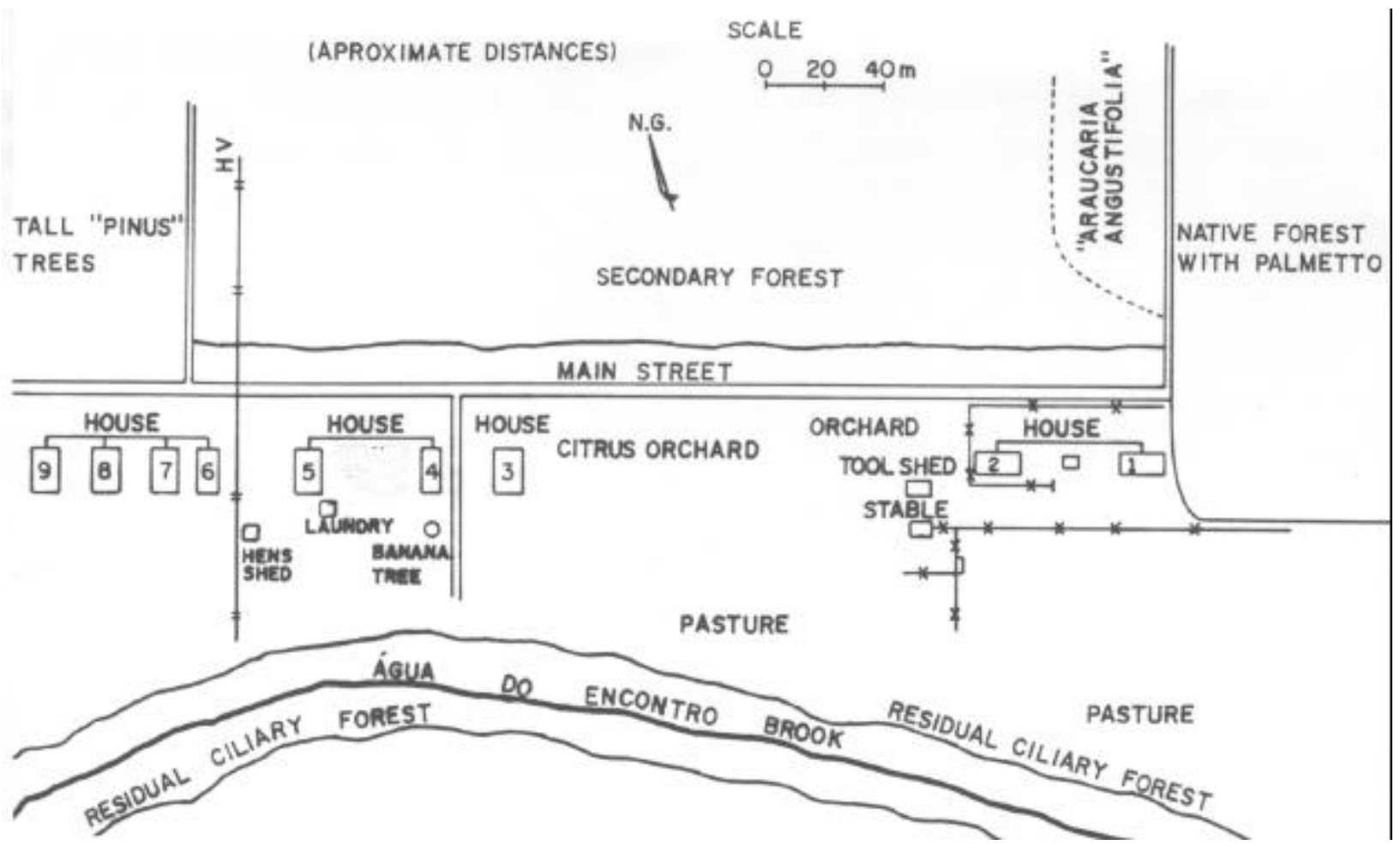

Figure 2: Falcão traps installed inside hens shed, laundry, banana trees, stable, house 1 and in the same location from which the pigsty was removed, after prophylactic measures in February, March and April 1994, in Jussara Farm, Parana State, and Brazil. 
The domestic animal shelters (pigs, hens, dogs and others) were made in a rough and disorganised way, and were located very close to the inhabited houses.

Before the second phlebotomines collection phase, a number of sanitation measures were implemented e.g. domestic sewage had to be channelled in to aseptic holes; animal shelters were moved as far away as possible from the houses $(100 \mathrm{~m})$; a few trees were cut to improve soil exposition to the sun light reducing humidity; organic matter accumulated in the environment (leaves, animal faeces, decomposing fruits) were removed, keeping the yards clean. The measures were implemented during January 1994, creating conditions for a new series of collection in a sanitised and a better-organised environment.

In the second phase, phlebotomine collections were made with six Falcão traps. The traps were again installed from 9:00 to 12:00 p.m., during five consecutive days in the months of February and March and four days in April 1994, in the first half of each month in the domicile and peridomicile area (Fig. 2). In this phlebotomine collection phase, the locations of the traps were not exactly the same as in the first phase (due to environment modifications). All the same, the traps which could not coincide were installed as close as possible to the first phase places (Figure $1,2)$ in the following way:

A. In the same place where a pigsty was (P1) and trap $\mathrm{P}$ was installed;

B. Within houses 1 (R1);

C. Among the banana-trees (B) at the back of house 4;

D. In the hens shed (G1) between houses 5 and 6 , at the back;

E. In the washing place (L) between houses 4 and 5 , at the back;

F. In the shed (E1), with no horse.

The results of the two phlebotomines collecting phases have been compared with respect to the Hourly Average capture (AH) of the Diptera.

\section{RESULTS AND DISCUSSION}

The results obtained during the phlebotomines collections in February, March and April 1992 showed that the density of Diptera was very high. The samples collected belonged to the genera Brumptomyia and Lutzomyia. The species of phlebotomine collected were:

1. Brumptomyia brumpti (Larrousse, 1920), 2. Lutzomyia (Nyssomyia) neivai (Lutz \& Neiva , 1912),

3. Lutzomyia migonei (França, 1920),

Lutzomyia (Pintomyia) fischeri (Pinto, 1926),

5. Lutzomyia (Psathyromyia) shannoni (Dyar, 1929),

6. Lutzomyia (Nyssomyia) whitmani (Antunes \& Coutinho, 1939),

7. Lutzomyia (Pintomyia) pessoai (Coutinho \& Barretto, 1940),

8. Lutzomyia firmatoi (Barretto, Martins \& Pellegrino, 1956).

In the first phase of collections, the species dominant was Lutzomyia whitmani $(84,4 \%), L u$ intermedia (8,1\%), Lu migonei (5\%) and others (2,5\%) (Table 1). In the second phase $L u$ whitmani was still dominant. However, $L u$. intermedia was the species with best adaptation. Its population during the first period represented $8,1 \%$ which in the second collection phase reached $28,39 \%$. In the micro-foci, where the study was developed, the houses were near a small Wood strip (East) as bordering forest along the creek, and a NNW has a reforestation area, allowed for the proliferation of phlebotomine and explained the presence of a large number of sandflies as well as the diversity of species found in the domiciliar and peri-domiciliar areas. In the first phase, a total 35,783 phlebotomines were collected during $9 \mathrm{~h}$, giving an Hourly Average (HÁ) of 3,976 phlebotomines. In the second phase a total 6,311 phlebotomines were trapped in $42 \mathrm{~h}$, giving an Hourly Average of 150 phlebotomines. The collected samples belonged to the same Brumptomyia and Lutzomyia genera (Table 1). Comparing 1992 results $(\mathrm{HA}=3,976)$ with 1994 's $(H A=150)$, it was evident that the phlebotomine population suffered a very marked decrease, with relation to all of the species. 
Looking at the traps results in the collecting phases, one could see that in the second phase the hour frequency averages were lower in all of the traps with a definite reduction in the phlebotomines number for all the traps $(\mathrm{R}, \mathrm{R} 1 ; \mathrm{P}$, $\mathrm{P} 1 ; \mathrm{E}, \mathrm{E} 1 ; \mathrm{C}, \mathrm{L} ; \mathrm{G}, \mathrm{G} 1)$ where a correlation could be made (Table 2).
Environment factors (high humidity, organic compounds) and economic level of population (low income, lack of hygienic conditions) might account for the increased presence of phlebotomine in the peri-domiciliar area and as a consequence, an increased transmission of cutaneous leishmaniasis (WHO, 1990).

Table 1: Total numbers and Hourly Average (HA) of all phlebotomine species collected using Falcão traps in domiciles and domestic animals shelters, beside the forest orchard of Jussara farm, Jussara municipality, Paraná State, Brazil, in February, March and April, 1992 and 1994.

\begin{tabular}{lcccccccc}
\hline \multicolumn{1}{c}{ Year } & \multicolumn{3}{c}{1992} & \multicolumn{4}{c}{1994} \\
\hline \multicolumn{1}{c}{ Species } & Female & Male & Total & HA & Female & Male & Total & HA \\
\hline Lutzomyia whitmani & 25,585 & 4,603 & $\mathbf{3 0 , 1 8 8}$ & 3,354 & 3,608 & 775 & $\mathbf{4 , 3 8 3}$ & 104 \\
Lutzomyia neivai & 1,821 & 1,094 & $\mathbf{2 , 9 1 5}$ & 324 & 1,027 & 765 & $\mathbf{1 , 7 9 2}$ & 43 \\
Lutzomyia migonei & 1,316 & 452 & $\mathbf{1 , 7 6 8}$ & 196 & 14 & 66 & $\mathbf{8 0}$ & 1.9 \\
Lutzomyia fischeri & 54 & 264 & $\mathbf{3 1 8}$ & 35 & 19 & 10 & $\mathbf{2 9}$ & 0.7 \\
Lutzomyia pessoai & 181 & 79 & $\mathbf{2 6 0}$ & 29 & 13 & 11 & $\mathbf{2 4}$ & 0.6 \\
Lutzomyia firmatoi & 1 & 5 & $\mathbf{6}$ & 0.7 & 3 & - & $\mathbf{3}$ & - \\
Lutzomyia shannoni & 5 & - & $\mathbf{5}$ & 0.6 & - & - & - & - \\
Lutzomyia spp. & 319 & - & $\mathbf{3 1 9}$ & 35.4 & - & - & - & - \\
Brumptomyia brumpti & 3 & 1 & $\mathbf{4}$ & 0.4 & - & - & $\mathbf{2}$ & - \\
\hline \multicolumn{1}{c}{ Total } & 29,285 & 6,498 & $\mathbf{3 5 , 7 7 9}$ & 3,976 & 4,684 & 1,627 & $\mathbf{6 , 3 1 3}$ & 150 \\
\hline
\end{tabular}

* Species non-identified because it has lost wings, antennae or mouthparts.

The improved organisation and sanitation of the peri-domiciliar area with the appropriate disposal of organic waste, reduction in humidity, trees and animals were the probable cause for the decrease of phlebotomine in the environment. Undoubtedly, domestic animals represented an attractive force for phlebotomines and evidently there removal from the environment reduced the blood for feeding and consequently reduced the population of the sandflies. The lowering of the sandflies population in 1994 could also be attributed to the climatic modification or to the environmental manipulations instigated by the trapping made in 1992. However, in 1992 and 1994, weather conditions did not differ significantly and could not explain the total decrease in the phlebotomine population (Table 3).

Table 2: Totals and Hour Averages (HA) of phlebotomines collected with a Falcão trap, in domicile environment and domestic animals shelters, beside the forest orchard of Jussara farm, Jussara municipality, Paraná State, Brazil, in February, March and April, 1992 and 1994.

\begin{tabular}{cccccccc}
\hline \multicolumn{1}{c}{1992} & & \multicolumn{5}{c}{1994} \\
\hline Trap & $\begin{array}{c}\text { Total } \\
\text { insects }\end{array}$ & HA* & $\%$ & Trap & $\begin{array}{c}\text { Total } \\
\text { insects }\end{array}$ & HA** & $\%$ \\
\hline $\mathrm{R}$ & 248 & $\mathbf{2 8}$ & 0.69 & $\mathrm{R} 1$ & 163 & $\mathbf{4}$ & 2.58 \\
$\mathrm{P}$ & 2,357 & $\mathbf{2 6 2}$ & 6.4 & $\mathrm{P} 1$ & 610 & $\mathbf{1 5}$ & 9.66 \\
$\mathrm{E}$ & 13,217 & $\mathbf{1 , 4 6 9}$ & 36.8 & $\mathrm{E} 1$ & 953 & $\mathbf{2 2}$ & 15.1 \\
$\mathrm{~T}$ & 148 & $\mathbf{1 6}$ & 0.4 & $\mathrm{~B}$ & 1,179 & $\mathbf{2 8}$ & 18.7 \\
$\mathrm{C}$ & 2,235 & $\mathbf{2 4 8}$ & 6.2 & $\mathrm{~L}$ & 1,306 & $\mathbf{3 1}$ & 20.7 \\
$\mathrm{G}$ & 17,783 & $\mathbf{1 , 9 5 3}$ & 49.7 & $\mathrm{G} 1$ & 2,100 & $\mathbf{5 0}$ & 33.3 \\
\hline Total & 35,783 & $\mathbf{3 , 9 7 6}$ & 100 & Total & 6,311 & $\mathbf{1 5 0}$ & 100 \\
\hline
\end{tabular}

*Values result from of the values from the previous column by 9; **Values result from the division from the previous column by 42 ; 
R; R1= Traps placed inside the inhabited houses;

$\mathrm{T} ; \mathrm{B}=$ In the varanda of an uninhabited house and among banana trees in the backyard of this house;

$\mathrm{C}$; $\mathrm{L}=$ in a dog kennel and in a laundry nearby after the removal of the kennel, respectively;

$\mathrm{E}$; E1= Inside a stable, with a horse serving as the bait, and in the same stable without the presence of the horse, respectively;

$\mathrm{G} ; \mathrm{G} 1=$ Inside a chicken shed in the backyard of a house, and in the same chicken shed relocated further from the house, respectively.

P; P1= Inside a pigsty in the backyard of a house and in the same location after the removal of the pigsty, respectively;

The use of insecticide as a means to control cutaneous and visceral leishmaniasis vectors has been quite common. This was basically due to the role DDT played in the control of malaria and thus indirectly reducing the incidence of leishmaniasis (Deane et al. 1955, Herrer 1956, Alencar 1961, Sherlock \& Almeida 1970, Sen Gupta 1975,

Magalhães et al. 1980, Le Pont \& Desjeux 1985, Brazil et al. 1992, Davies et al. 1994, Gratz \& Jany, 1994). At the same time, the prophylactic alternatives, aimed at the vectors control have been directed mainly against mosquitoes and triatomines (Le Pont \& Desjeux, 1984, Service 1991, Ault 1994, Winch et al. 1994).

Table 3: Ambiental conditions of Jussara farm, Jussara Municipality, Parana state, Brazil during two periods of sandflies collections.

\begin{tabular}{|c|c|c|c|c|c|c|}
\hline Year & \multicolumn{3}{|c|}{1992} & \multicolumn{3}{|c|}{1994} \\
\hline Mouth & FEB & MAR & APR & FEB & MAR & APR \\
\hline $\begin{array}{l}\text { Ploviometric } \\
\text { Precipitation } \\
\left(\mathrm{Mm}^{3}\right)\end{array}$ & 191 & 185 & 290 & 277,5 & 98 & 59,5 \\
\hline $\mathrm{Temp}^{\circ} \mathrm{C}$ & & & & & & \\
\hline Minimum & 22 & 20,8 & 18,3 & 22,1 & 21 & 19,4 \\
\hline Medium & 26,7 & 25 & 22,4 & 27 & 25,5 & 23,5 \\
\hline Maximum & 31,5 & 29,2 & 26,5 & 32 & 30 & 28,5 \\
\hline
\end{tabular}

The results of this study showed that environmental organisation and sanitation methods contributed to reduce the phlebotomines population in the human dwelling environment. As a consequence, it is probable that they can diminish leishmaniasis transmission to man and domestic animals (dogs) in these environments. These measures ought to be implemented in some more areas so that their efficacy could be better evaluated.

\section{RESUMO}

Foram comparados os resultados de coletas de flebotomíneos, realizadas na fazenda Jussara, no Município de Jussara, Paraná, Brasil. As primeiras coletas foram realizadas no ano de 1992, nos meses de Fevereiro, Março e Abril, antes de ter sido feito saneamento ambiental. Seis armadilhas de tipo Falção foram instaladas no domicílio e peridomicílio. Foram realizadas uma coleta por mês e um total de 35,783 flebotomíneos foram coletados. As espécies predominantes foram $\mathrm{Lu}$. whitmani (84.4\%), Lu intermedia (8.1\%), Lu migonei $(5.0 \%)$, e outros $(2.5 \%)$. Na primeira coleta a média horaria foi de 3.976 (353783/9). Baseado nestes dados foi realizado uma limpeza no peridomicílio em Janeiro de 1994 (canalização das águas usadas, retirada de madeiras empilhadas e de matéria orgânica, afastamento das habitações dos animais das residências humanas e corte de árvores). Após estas medidas foi realizado nova coleta nos meses de Fevereiro, Março e Abril de 1994, totalizando 42 horas. A média horária foi de $150(6.311 / 42)$ insetos. Prevaleceram Lu. whitmani $(70,4 \%)$, Lu neivai $(27,1 \%)$ e outros $(2,5 \%)$. As medidas de saneamento ambiental e o afastamento dos animais domésticos do peridomicílio podem servir como medidas auxiliares para o controle de flebotomíneos , atenuando a transmissão de Leishmania para o homem no peridomicílio, em áreas endêmicas de leishmaniose tegumentar.

\section{ACKNOWLEDGMENTS}

This work was supported by Fundação Nacional de Saúde and Cia. Melhoramentos Norte do Paraná. We thank Diarmid Campbell-Lendrum, London School of Hygiene and Tropical Medicine for the help in the preparation of the manuscript and Ashok Pandey, BiotechnologyUFPR for definitive correction. 


\section{REFERENCES}

Alencar JE (1961), Profilaxia do calazar no Ceará, Brasil. Rev Inst Med Trop São Paulo, 3, 175-180.

Ault SK (1994), Environmental management: a re-emerging vector control strategy. Am $J$ Trop Med. Hyg., 50 (Supl. 6), 35-49.

Brazil RP, Almeida DC, Ferreira DC \& Giordano-Dias CM (1992), Effect of fenthion, a systemic insecticide, on $L$. longipalpis (Diptera: Psychodidae) vector of visceral leishmaniasis. Mem Inst Oswaldo Cruz, 87 (Supl. II), 218.

Chaniotis BN, Parsons RE, Harlan HJ \& Correa M.A (1982), A pilot study to control phlebotomine sandflies (Diptera: Psychodidae) in a Neotropical rain forest. $J$ Med. Entomol., 19, 1-5.

Davies CR, Llanos-Cuentas A, Canales J, Leon E, Alavarez E, Monge J, Tolentino E, Gomero Q. Pyke S \& Dye C (1994), The fall and rise of Andean cutaneous leishmaniasis: transient impact of the DDT campaign in Peru. Trans Roy Soc. Trop Med. Hyg., 88, 389-393.

Deane LM, Deane MP \& Alencar JE (1955), Observações sobre o combate ao Phlebotomus longipalpis pela dedetização domiciliária em focos endêmicos de calazar, Ceará Rev bras Malar., 7, 131-141.

Falcão AR (1981), Um novo modelo de armadilha luminosa de sucção para pequenos insetos. Mem Inst. Oswaldo Cruz 76, 303305.

Gomes, AC, Rabello EX, Santos JLF \& Galati E.A.B (1980), Aspectos ecológicos da leishmaniose tegumentar americana. 1. Estudo experimental da frequência de flebotomíneos em ecótopos artificiais, com referência especial a Ps. intermedius. Rev Saúde Pública, 14, 540-556.

Gomes AC, Santos JLF \& Galati EAB (1986), Ecological aspects of american cutaneous leishmaniasis. 4. Observations on the endophilic behavior of the sandfly and vectorial role of Psychodopygus intermedius in the Ribeira Valley of the São Paulo State, Brazil. Rev Saúde Pública, 20, 280-287.
Gratz, NG \& Jany WC (1994), What role for insecticides in vector control programs? Am J Trop Med. Hyg.,50(Supl. 6), 11-20.

Herrer, A (1956), Repercussion del uso casero de los insecticidas en la incidência de la leishmaniasis tegumentaria del perro. Rev Med exper 20, 139-145.

Hertig M \& Fairchild GB (1948), The control of Phlebotomus in Peru with DDT. Am J Trop Med 28, 207-230.

Lainson R (1985), Our present knowledge of the ecology and control of leishmaniasis en the amazon region of Brasil. Rev Soc Bras Med Trop., 18,47-56.

Le Pont F \& Desjeux P (1985), Leishmaniasis in Bolivia. I. L. longipalpis (Lutz \& Neiva, 1912) as the vector of visceral leishmaniasis in los Yungas. Trans Roy Soc Trop Med Hyg., 79, 227-231.

Lima LCR, Marzochi MCA \& Sabroza PC (1981), Flebotomíneos em área de ocorrência de leishmaniose tegumentar no bairro de Campo Grande, Brasil. Rev bras Malar., 33, 64-74.

Lima LC, Marzochi MCA, Sobroza PC \& Souza M A (1988), Observções sobre a leishmaniose tegumentar, cinco anos após profilaxia. Rev Saúde Pública, 22, 73-77.

Magalhães PA, Mayrink W, COSTA C, Batista SM, Michalik MSM \& Williams P (1980), Calazar na zona do Rio Doce - Minas Gerais. Resultados de medidas profiláticas. Rev Inst Med Trop São Paulo, 22, 197-202.

Marsden PD (1985), Pentavalent antimonial: Old drugs for new diseases. Rev Soc Bras Med. Trop., 18, 187-198.

Marsden PD (1986), Mucosal leishmaniasis ("espundia" Escomel 1911). Trans Roy Soc Trop Med Hyg., 80, 859-876.

Mattos EA (1981), Bionomia dos flebotomíneos de Perobas, município de Viana (ES), área endêmica de leishmaniose tegumentar americana. MSc Thesis. Belo Horizonte, Brasil, 130.pp.

Nery-Guimarães F \& Bustamente FM (1954), A aplicação domiciliária de DDT como base da profilaxia das leishmanioses. Estudo de um foco de leishmaniose muco-cutâneo cinco anos depois de aspersão periódica com aquele inseticida. Rev bras Malar., 6, 127-130.

Sen Gupta PC (1975), Return of Kala-azar. $J$ Indian Med Ass., 65, 89-90. 
Service MW (1991), Agricultural development and arthropod-born diseases: a review. Rev Saúde Pública, 25, 165-178.

Sherlock IA \& Alameida SP (1970), Observações sobre calazar em Jacobina, Bahia. V. Resultados de medidas profiláticas. Rev bras Malar., 22, 175-182.

Teodoro U (1995). Caraterísticas ecológicas de flebotomíneos (Diptera, Psychodidae) em habitatas antrópicos, município de Jussara, Paraná, Brasil. Curitiba. $\mathrm{PhD}$ Thesis, Curitiba, Brasil, xx + 178 pp.

Teodoro U, Spinosa RP, La Salvia F. V, Guilherme ALF, Lima AP, Junqueira GMB, Misuta NM, Nerilo Sobrinho A \& Lima EM (1991), Da necessidade de se adotar e divulgar esquemas terapêuticos para tratamento de leishmaniose tegumentar no Paraná. Rev. Inst. Med. Trop. S. Paulo, 33, 199-204.
Teodoro U, LA Salvia $F^{\circ}$ V, Lima EM, Spinosa RP, Barbosa OC, Ferreira MEMC \& Lonardoni MVC (1993), Observações sobre o comportamento de flebotomíneos em ecótopos florestais e extraflorestais, em área endêmica de leishmaniose tegumentar americana, no norte do Estado do Paraná, sul do Brasil. Rev. Saúde Pública, 27, 242-249.

Ward, RD (1977), New World leishmaniasis: a review of the epidemiological changes in the last three decades. In: International Congress of Entomology, 15², Washington, 1977. Proceedings. Washington, DC. p.505-522.

Winch PJ, Lloyd LS, Hoemeke L \& Leontsini E (1994), Vector control at the household level: an analysis of its impact on women. Acta tropica ,56, 327-339. 